\title{
Instant Flood Risk Modelling (Inform) Tool for Co-Design of Flood Risk Management Strategies with Stakeholders in Can Tho City, Vietnam
}

\author{
Hieu Ngo ${ }^{1,2, *}$, Mohanasundar Radhakrishnan ${ }^{1}$, Roshanka Ranasinghe ${ }^{1,3,4}\left(\mathbb{D}\right.$, Assela Pathirana ${ }^{1}(\mathbb{D})$ \\ and Chris Zevenbergen ${ }^{1,2}$ \\ 1 Department of Coastal and Urban Risk and Risk Resilience, IHE Delft Institute for Water Education, \\ P.O. Box 3015, 2601 DA Delft, The Netherlands; m.radhakrishnan@un-ihe.org (M.R.); \\ r.ranasinghe@un-ihe.org (R.R.); a.pathirana@un-ihe.org (A.P.); c.zevenbergen@un-ihe.org (C.Z.) \\ 2 Department of Hydraulic Engineering, Faculty of Civil Engineering and Geosciences, \\ Delft University of Technology, P.O. Box 5048, 2628 CN Delft, The Netherlands \\ 3 Department of Water Engineering and Management, University of Twente, P.O. Box 217, \\ 7500 AE Enschede, The Netherlands \\ 4 Harbour, Coastal and Offshore Engineering, Deltares, P.O. Box 177, 2600 MH Delft, The Netherlands \\ * Correspondence: h.ngo@un-ihe.org; Tel.: +31-687699329
}

check for updates

Citation: Ngo, H.; Radhakrishnan, M.; Ranasinghe, R.; Pathirana, A.; Zevenbergen, C. Instant Flood Risk Modelling (Inform) Tool for Co-Design of Flood Risk Management Strategies with Stakeholders in Can Tho City, Vietnam. Water 2021, 13, 3131. https://doi.org/10.3390/w13213131

Academic Editor: Pankaj Kumar

Received: 10 October 2021

Accepted: 4 November 2021

Published: 6 November 2021

Publisher's Note: MDPI stays neutral with regard to jurisdictional claims in published maps and institutional affiliations.

Copyright: (c) 2021 by the authors. Licensee MDPI, Basel, Switzerland. This article is an open access article distributed under the terms and conditions of the Creative Commons Attribution (CC BY) license (https:/ / creativecommons.org/licenses/by/ $4.0 /)$.

\begin{abstract}
Flood risk reduction strategies play an important role in flood risk management (FRM) and these strategies are being co-designed with the engagement of the stakeholder through multiple consultations and co-designing sessions. Effective participation of stakeholders in interactive work sessions requires fast and accurate modeling systems with a user-friendly interface, which can simulate the impact due to various flood reduction measures selected by the stakeholders and also generate outputs that can be understood by all stakeholders, especially those who are not FRM specialists. Presenting an easy-to-understand tool with easy inputs and outputs for a variety of stakeholders and at the same time providing reliable and accurate results for a range of scenarios and interventions is a challenge. Seven requirements that are essential for a user-friendly flood risk tool were used to develop an instant flood risk modeling tool. This paper presents a web-based hydraulic tool, i.e., instant flood risk model (Inform), to support FRM in the urban center of Can Tho city (Ninh Kieu district), Mekong Delta, Vietnam. Inform was developed based on (i) a simplified 1D model for the entire Mekong Delta; and (ii) flood hazard and damage maps, and estimated flood damage for Ninh Kieu district in Can Tho city obtained directly from the 1D/2D coupled model for Ninh Kieu district. Inform rapidly generates flood levels, flood hazard and damage maps, estimated damages. Pilot testing with experts confirmed that Inform qualifies as a reliable co-design tool for developing FRM strategies as it features an inbuilt input library, comprises flexible options, easy to use, produces quick results and has a user-friendly interface. With the help of an interactive web-based tool such as Inform presented here, it is possible to co-design FRM strategies for Can Tho or any other city that is subject to flood risk.
\end{abstract}

Keywords: flood risk management; web-based tool; Mekong Delta; Can Tho city

\section{Introduction}

Flooding is one of the most frequently occurring and damaging natural disasters worldwide [1-6]. Approximate 250 million people in the world are affected by floods every year [7], and the annual average economic losses have exceeded 40 billion USD in recent years [8]. Developing flood risk reduction strategies to minimize damage caused by floods is the primary objective of any FRM strategy. Collaborative learning and designing among stakeholders are an increasing trend in local FRM [9-11]. The importance of stakeholder engagement (e.g., citizens and interest groups, businesses, officials, and decision-makers) in the selection and implementation of flood risk reduction measures is widely acknowledged. 
Stakeholders are also increasingly involved in the design phase of measures supported by user-friendly flood risk models, such as in the Dutch Room for the River program [12]. The effectiveness and success of co-designing sessions have been demonstrated by the Blokkendoos tool $[13,14]$ used within the Room for the River program in the Netherlands. In interactive sessions supported by the Blokkendoos tool, stakeholders participated in the design process using 'what-if scenarios' to explore the impact of various interventions on the flood level as well as the flood risk in the study area, which allowed them to prioritize interventions and to engage in an inclusive decision-making process.

Effective participation of stakeholders in interactive work sessions requires a fast and accurate modeling system with a user-friendly interface, which can simulate the user's interventions to provide outputs that can be understood by all stakeholders, especially those who are non-FRM specialists. These features have been identified as the most sought-after attributes of flood simulation models to support practitioners in flood disaster management [15].

This paper presents an interactive, web-based tool, Inform, which was developed based on: (i) a simplified 1D model for the entire Mekong Delta; and (ii) flood hazard and damage maps, as well as on estimated impacts (direct damage) for the urban center of Can Tho city-Ninh Kieu district in Vietnam obtained directly from the 1D/2D coupled model for Ninh Kieu district. Inform is designed with the aim of satisfying the above-mentioned user requirements, allowing users to assess different scenarios and receive visual outputs within one minute. Pilot testing with experts to evaluate the tool's key features (e.g., user interface, the effectiveness of the tool and its outputs) was conducted. For the evaluation, seven criteria were used, which were extracted through an extensive review of literature on interactive tools [15-30]. Inform is used here to demonstrate how it can be used to support rapid flood risk assessment to facilitate a co-designing approach aiming at exploring, identifying and selecting flood risk reduction measures for Ninh Kieu district with the stakeholders' participation.

The content of this paper is structured as follows: Section 2 presents the literature review on the challenges of generating interactive tools to support FRM; addressing challenges using an interactive tool for Can Tho is presented in Section 3; pilot testing and evaluation of Inform is presented in Section 4; followed by a discussion in Section 5; and Section 6 presents conclusions of this paper.

\section{Challenges in Creating Interactive Tools to Support FRM}

Communicating the effectiveness of FRM interventions across stakeholders is imperative in co-designing FRM interventions. The effectiveness of FRM interventions is an important strand of information that should be understood and easily be visualized. The visualization can be in the form of a simple infographic or a detailed three-dimensional real-life virtual tour of the FRM measures under consideration. There are freely available tools in countries such as The Netherlands and UK, which give information on long-term flood risk for an area, possible causes of flooding and how to manage flood risk [31,32]. Additionally, organizations such as Melbourne Water in Australia issue flood level certificates that contain information about flood levels and the probability of occurrence of flooding at the property level [33]. These are awareness creation or risk information dissemination platforms that are meant to present expert domain knowledge in a form that the general public can easily understand.

The common feature among all of the aforementioned online platforms and interactive visualizations is that the entire process of hydraulic modeling is completed beforehandupdated periodically - with or without the possible combination of FRM measures and is stored in a database. Some online tools have an interactive front-end that allows the user to select a postcode for which the flood risk and probability of flooding are retrieved from the database and results are displayed instantly either in the form of a map or as text (e.g., [31,32]). However, these tools do not have options for the user to perform 'what-if 
scenarios' to explore the impact of various interventions on the flooding level as well as the flood risk in the study area.

Ideally, a platform should allow the user to change inputs such as river flow rate, rainfall intensity, water level and FRM measures through an easy-to-use graphical user interface (GUI); run a fast hydraulic model to determine the flood extents, duration and depths; use this information for calculation of immediate risks such as flood damage and long-term risks; and display the information in the form of online maps, tables and graphics. These outputs should be understandable to stakeholders, especially those who are non-FRM specialists. It must also be ensured that the tool is fast enough to perform simulations of a variety of scenarios based on selected user inputs to assess the flood risk reduction measures during a co-design work session. These are must-have features of co-design tools identified from a number of stakeholder interviews [15]. Additionally, the data preparation, processing and prerequisites have to be taken into account to develop an online flood risk tool that can help generate the details that are needed to ensure common understanding among various stakeholders during co-design work sessions.

The tool developers need to comply with a set of minimum requirements in order to create a user-friendly flood risk tool. These requirements are as follows:

\section{(1) Ensuring reliability of tool outputs}

The reliability of the tool is of utmost importance to the user [15]. Confidence in the outputs of modeling tools is paramount for the uptake of the tool by various stakeholders. For example, the user must have confidence that simulated flood depths and flood damages in the tidal urban sub-catchment of the river are reliable.

\section{(2) Ease of use and avoiding input overkill}

Differences often exist in the expertise and interest of stakeholders' participating in co-design work sessions [16-19]. These require that tool developers must have an understanding of the level of knowledge and information needs of potential users in order to use the tool effectively. Questions such as "does the tool require the user to bring in data?" and "should the user select all of the parameters to run the tool?" have to be considered by the developers at the tool design stage. Lack of detailed knowledge of the (local) hydrological context and technical aspects (for instance about the specifications of interventions), difficulties in understanding the instructions and cognitive loading should not provide an impediment for a wide range of stakeholders to use the tool $[20,21]$.

\section{(3) Time taken to generate tool outputs}

Co-design work sessions typically last a few hours [22], therefore, they call for models to be fast enough to provide multiple outcomes and foster iteration during a single work session [15]. Questions such as "how long does the user need to spend on selecting the input parameters and how long does the user have to wait to get the outcomes?" and "what is the acceptable waiting time between the selection of inputs and the display of results?" have to be considered in the development phase of the tool.

\section{(4) Transcending coarser and finer resolutions across spatial scales}

A flood risk tool that allows the user to identify the flood risk and to assess the effectiveness of adaptation actions across various locations and spatial scales will contribute to the flood risk knowledge base of the various stakeholders active in the delta or catchment area. This in turn offers conditions for collaboration and joint actions. The following questions seem to be relevant in this context: Is the tool capable to simulate flooding across spatial scales from a catchment of the size of the Mekong Delta and to an urban area whereby the information (flood delineation and damages) provided has sufficient resolution to support multi-level governance decision-making? For example, the knowledge of local people (including their perceived vulnerability) on the effectiveness and feasibility of adaptation actions they can take individually at the local scale or collaboratively at a larger spatial scale may incentivize them to act and thus increase their ability to frame, understand and influence their flood and climate change risks [23,24]. 


\section{(5) Transcending coarser and finer resolutions across temporal scales}

What are the time scales relevant for the tool? A tool which supports high-level strategic decision making and can explore pathways to future flood protection, warrants to simulate flooding and to compute flood damages covering a time horizon of at least 50 years given the long lead times of large interventions. In addition, stakeholders' engagement and responses are influenced by how risk is presented, and the time factor is very important in risk communication as there is a physiological distance or disconnect of long-term risks or impacts such as climate risk $[25,26]$. Hence it is imperative to generate data to elucidate the long-term potential impacts and the lead time of adaptation actions.

\section{(6) Interpretation and relevance of tool outputs across a wide spectrum of stakeholders}

The tool outputs should support decision-making at the strategic policy planning level, project planning and implementation level, and also at the operational level to create awareness among the general public. It is of utmost importance that the stakeholder needs are identified and what they actually want to know. Moreover, the stakeholders should have the ability to interpret the outputs [27], which latter often requires guidance.

\section{(7) Assessing the effectiveness of FRM measures}

Delivery of risk information without suitable actions to minimize or eliminate risk can cause concern and anxiety among stakeholders $[28,29]$. How effective are the planned FRM measures in reducing flood damages? Can the effectiveness of FRM initiatives at multiple levels be assessed using the tool? For example, the effectiveness of FRM actions from the Mekong Delta Plan [30] is crucial information at the strategic planning level, whereas the effectiveness of retrofitting and elevating the floor level of houses as property level is relevant information for the city committee and citizens.

Addressing the aforementioned challenges will provide the conditions required for the development and acceptance of a useful flood risk gaming tool to support FRM. Some of the challenges, such as reducing the waiting time can be resolved using computational techniques. In contrast, challenges such as integration of FRM measures need to be dealt with from the perspective of FRM planners, and challenges such as versatility need to be understood from a human-machine interface perspective.

\section{Instant Flood Risk Model (Inform) for Co-Designing FRM in Can Tho}

The instant flood risk modeling tool (Inform) for Can Tho is an interactive web-based tool that provides within a short time an estimate of flood water level at Can Tho. Inform generates flood inundation (flood extent and inundation depth), flood damage maps, and flood damage for Ninh Kieu district in Can Tho city corresponding to a single flood event based on user-defined inputs (https://fg.srv.pathirana.net/; accessed on 5 October 2021) [34]. The underlying flood hazard and risk data are extracted from [35] while users are provided with the option of testing how certain adaptation measures may affect the flood hazard and/or risk. Inform covers the entire Mekong Delta, including Can Tho city which has an important demographic and economic significance [36,37]. Screenshots of inputs and outputs of the Inform are presented in Figure 1.

Inform addresses the identified user-requirement challenges encountered in developing an interactive FRM co-design tool and can be used in FRM domains such as strategic planning, city administration, project implementation and community engagement in Can Tho. The application of Inform in Can Tho and its compliance with the seven essential requirements are explained below. 

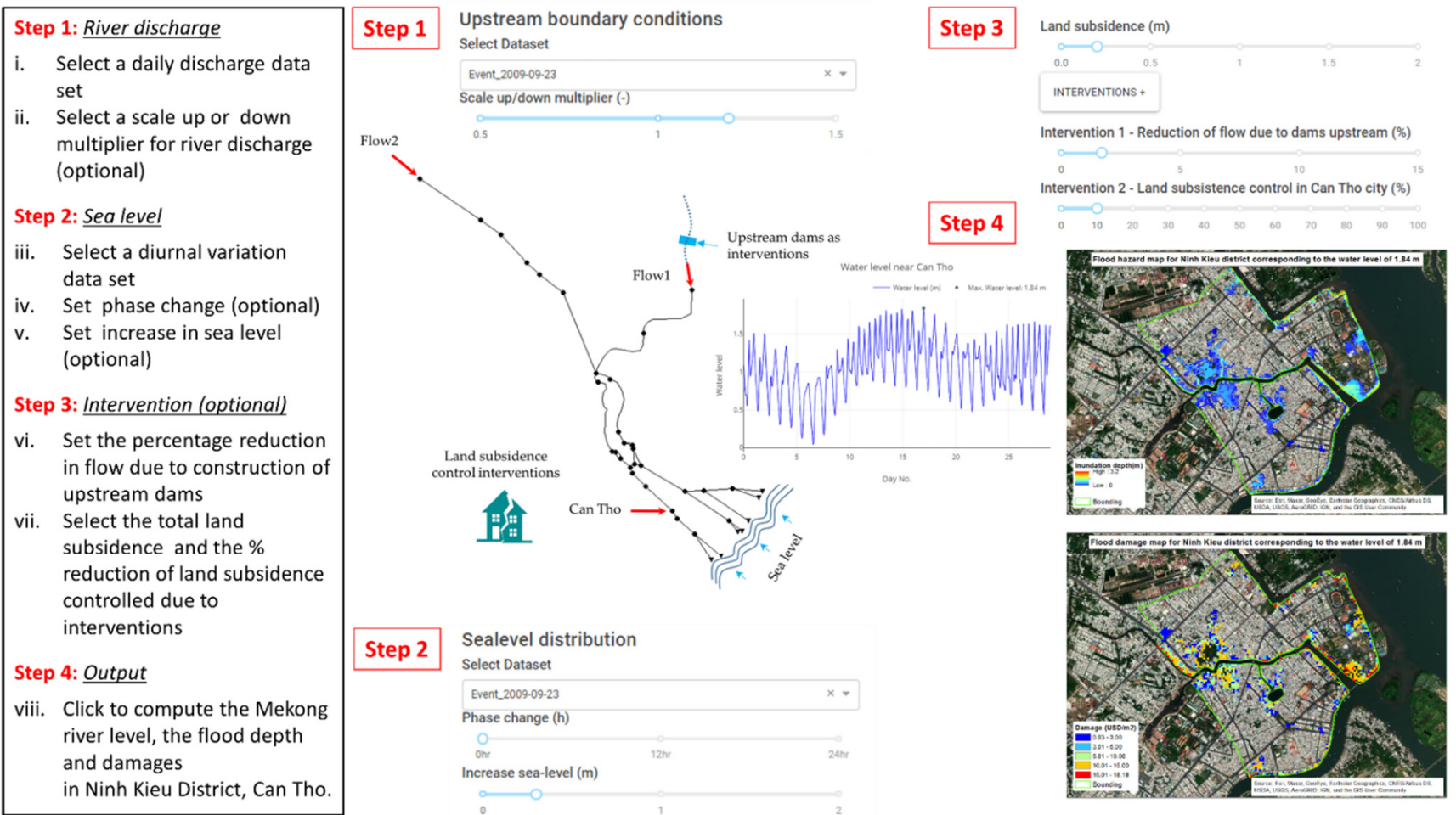

Figure 1. Flood risk tool (Inform) for Can Tho-inputs and outputs.

\section{(1) Ensuring reliability of tool outputs}

The background engine of Inform comprises: (i) a simplified, calibrated and validated 1D SWMM model for the entire Mekong Delta to calculate the water levels of the Mekong River at Can Tho [38]; (ii) an output library comprising grid-level inundation depths computed through 1D/2D coupled PCSWMM simulations and interpolation methods for Ninh Kieu district of Can Tho city for a wide range of Mekong River water levels at Can Tho; and, (iii) a grid level flood damage calculation model based on depth-damage curves for the different type of assets in Ninh Kieu district.

Inform uses the modeled water levels at Can Tho to generate the flood hazard and compute the associated flood damages. Reliability of the 1D/2D coupled flood model results has been established by calibrating the model outputs against measured inundation depths and flood extent at the study area during historical flood events [39].

Additionally, the input data for Inform including historical flood events at Kratie and sea level data at the Mekong River mouths from 2000 to 2009 were collected from reliable sources (e.g., Mekong River Commission, National Hydro-meteorological Service of Viet Nam). Therefore, Inform can provide reliable outputs based on the user-defined inputs.

\section{(2) Ease of use and avoiding input overkill}

The necessary input data for Inform is already processed and stored in a database. Hence the user does not need to collect additional data, which avoids input overkill. From the Inform database, the user selects only six input parameters through a graphical user interface to generate the outputs. Two additional selections must be made in case if outputs for FRM intervention are required. The user inputs to Inform, which are selected from the existing database using a drop-down menu, and data ranges are:

(i) upstream boundary condition of Mekong River at Kratie-i.e., flows at upstream of TonleSap (Western flows) and river flows at Kratie in the Mekong River (Eastern flows) and a scale factor to change the river flows. The scale factor is the ratio that the user wants to change the original river flow. The scale factor is used when the user wants to estimate the change in the river flow due to the effect of climate change to 
compute the resulting flood water level in Can Tho and the associated flood damage in Ninh Kieu district in the future compared with the past flood event.

(ii) sea level at the Mekong River mouths, which are the downstream boundary condition at East Sea-i.e., the diurnal variation of sea level for select dates from the drop-down menu, phase change of diurnal variation (the phase change represents a future change in the shape of sea level time series during a flood event, which can lead to changes in the river water level in Can Tho and the resulting flood damage in Ninh Kieu district) and increase in the amplitude of sea level (the change in amplitude represents a future increase in sea-level rise due to the effect of climate change).

(iii) land subsidence at Can Tho, which reduces the elevation of the ground surface. As a result, the inundation depth in Ninh Kieu district will increase when computing flooding, resulting in an increase in flood damage.

(iv) FRM interventions-upstream interventions such as dams and reservoirs that can reduce a certain percentage of river flow (input), and avoiding damages by controlling land subsidence, where the rate of land subsidence and percentage reduction in land subsidence are inputs. Upon selection of these inputs, the user can activate the hydraulic models and flood damage calculation models with one click of the mouse.

\section{(3) Time taken to generate tool outputs}

The time taken to make choices of the eight input parameters (six basic parameters and two for FRM interventions) required for Inform is a few minutes, for a user conversant with standard inputs to a hydraulic model. After these inputs are selected, it takes about one minute for Inform to generate the following outputs: (i) the maximum water level in the river and its timing at Can Tho; (ii) map showing the maximum flood depth in every grid cell in Ninh Kieu district; (iii) the flood damage due to inundation in Can Tho in million USD; (iv) map showing the damage in every grid cell due to inundation in Ninh Kieu district in USD per square meter. A conversant user can get the outputs within 2 min, including the input selection time, whereas for a beginner it would be between 5 to $10 \mathrm{~min}$ depending on their level of knowledge with the input.

\section{(4) Transcending coarser and finer resolutions across spatial scales}

The Inform output can help the strategic planners to determine optimal protection levels for FRM infrastructure, preparedness measures for the study area and develop appropriate policies to support FRM and strategize delta planning [40]. More specifically, the river water level generates maximum inundation depths at grid level in the city center (Figure 2) and will help identify the flood hazard in those grid cells, which would help the determination of flooding hotspots. The flood hazard map can also help the city officials to identify critical infrastructure and community at the risk of flood by overlaying the inundation map on their critical infrastructure and demography GIS database. Grid level flood hazard details from Inform can lead to the development of flood hazard ranking of grid cells or community pockets, which is a vital piece of information to channelize relief actions in the event of flooding. This will aid the city administration to contextualise the flood risk problem in Can Tho and help planning, implementation and coordination of FRM and relief measures in the near future or in the long term [41].

Inform calculates the total flood damage in the Ninh Kieu district for the selected river flow - sea level combination, and the map illustrates the grid level flood damages in USD per $\mathrm{m}^{2}$ (Figure 2). From this map, it can be inferred that the damages vary across the grids in the Ninh Kieu district. At the coarser scale, the total flood damage information can be useful for strategic delta planning as it can help policy-makers understand the impact of flooding in monetary terms in the most populous city and the hub of economic activity in the Mekong Delta. The total damages for different river flow-sea level combinations can help the city administrators to establish the range of monetary loss due to the past events and can help them prepare in terms of creating a reserve to compensate for future losses or to start formulating plans for FRM interventions to avoid or minimize flood risk. 


\section{Flood inundation}

\section{Estimated damage due to the flood event 2.73 mil. USD}
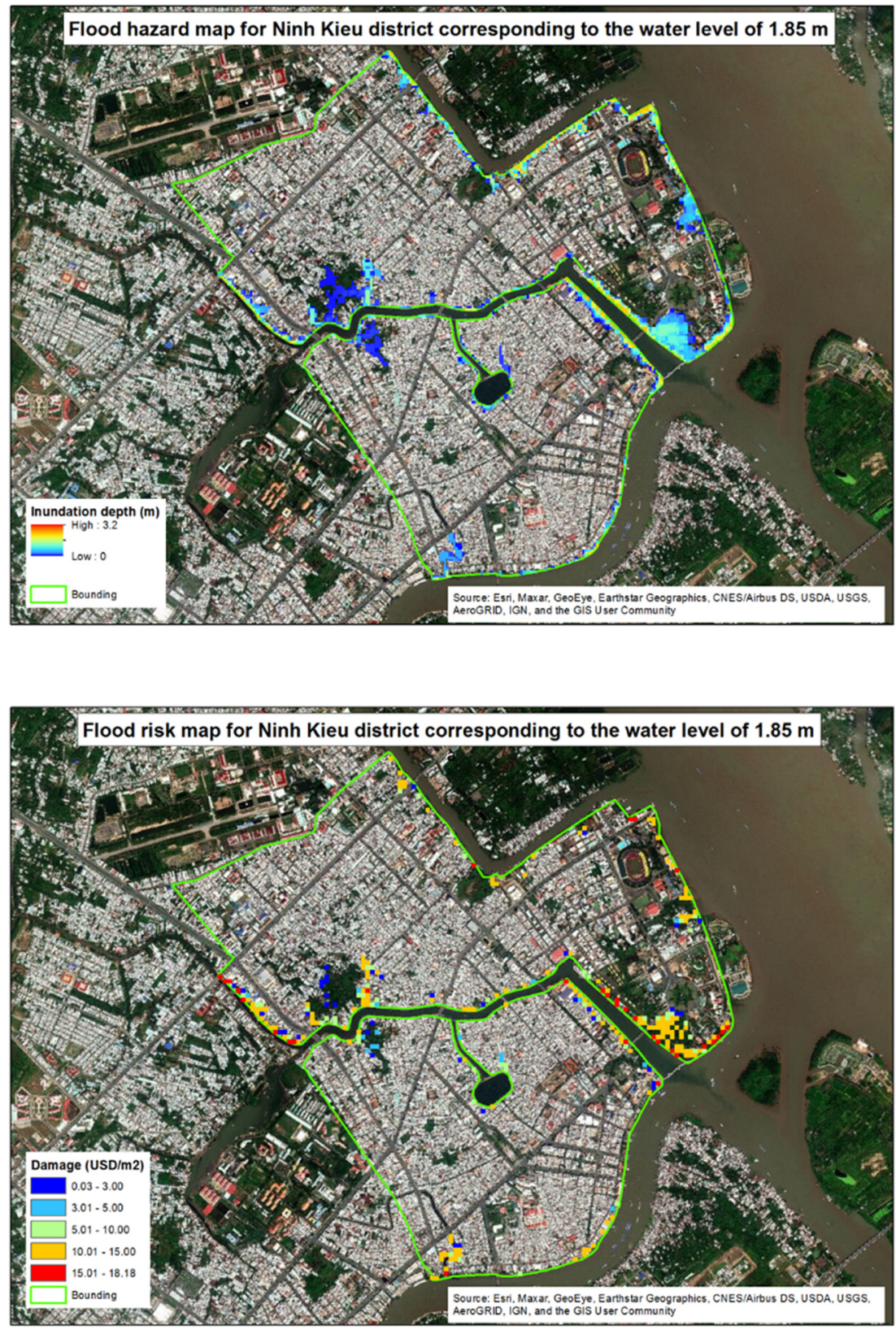

Figure 2. The inundation map, flood damage map, and the estimated total flood damage due to the flood event for the Ninh Kieu district, Can Tho city.

\section{(5) Transcending coarser and finer resolutions across temporal scales}

The river flow data and sea level data in Inform tool contains actual data from past events, which can generate historical flood events. However, what makes Inform interesting is the scale factor that can be applied to the river flows and increase in sea level that enables the user to make the changes to the historic data to explore 'what if scenarios' of present and future. The effect of climate change through the increase in sea level at the Mekong estuary mouths and the river flows was clearly evident through different future flood extents in Can Tho for a climate scenario such as the IPCC climate scenarios 
(i.e., RCPs). As mentioned earlier, the data for the Inform output library was obtained through the 2D modeling of flood depths and extent for various levels of the Mekong River level. The timing of occurrence of the plausible future water levels of the Mekong River in various IPCC scenarios was obtained from discharge projections calculated by Hoang et al. (2016) [42]. For example, with the help of Inform, the user can adjust the inputs to compute what would be the estimated flood damage of an event that has a similar return period of the flood event in the year 2000 flood if it occurs in 2050 under RCP4.5 or RCP8.5. The flood in the year 2001 was a 1 in a 0.3-year event. In the future, due to the impact of climate change, a 1 in the 0.3 -year event would correspond to an increase in $20 \%$ of upstream flows (compared to the year 2001 flood flow) together with a $0.2 \mathrm{~m}$ and $0.3 \mathrm{~m}$ increase in downstream sea level, in the RCP 4.5 and RCP 8.5, respectively. These changes in river flows and sea levels can be given as inputs in Inform by using the scale-up/down and increase in sea level options, and the corresponding river level and flood damages can be obtained (Table 1).

Table 1. The maximum water level in Can Tho and estimated damage in the Ninh Kieu district for historical flood events in 2001 ( 1 in 0.3 years) and flood events of same return period reoccurring in 2050 based on user-defined inputs under RCP 4.5 climate scenarios and RCP 8.5 .

\begin{tabular}{ccccccc}
\hline & \multicolumn{2}{c}{ Past } & \multicolumn{2}{c}{2050 (RCP 4.5) } & \multicolumn{2}{c}{ 2050 (RCP 8.5) } \\
\cline { 2 - 7 } Selected Event & $\begin{array}{c}\text { Maximum } \\
\text { Water Level } \\
(\mathbf{m})\end{array}$ & $\begin{array}{c}\text { Estimated } \\
\text { Damage } \\
(\text { Mil. USD) }\end{array}$ & $\begin{array}{c}\text { Maximum } \\
\text { Water Level } \\
(\mathbf{m})\end{array}$ & $\begin{array}{c}\text { Estimated } \\
\text { Damage } \\
\text { (Mil. USD) }\end{array}$ & $\begin{array}{c}\text { Maximum } \\
\text { Water Level } \\
(\mathbf{m})\end{array}$ & $\begin{array}{c}\text { Estimated } \\
\text { Damage } \\
(\text { Mil. USD) }\end{array}$ \\
\hline $\begin{array}{c}\text { The 2001 flood event } \\
(1 \text { in 0.3 years })\end{array}$ & 1.75 & 2.53 & 1.99 & 4.70 & 2.07 & 7.72 \\
\hline
\end{tabular}

Users with access to the river flow data, such as city council, irrigation department and researchers can use the tool to create comparative information based on the Mekong River water level for various return periods. For example, the flood extent in the year 2020 in Ninh Kieu district for a 1 in 100-year return period Mekong water level (2.15 m) is 12.7\% (Figure 3). However, the flood extent in the year 2050 in Ninh Kieu district for a 1 in 100-year return period Mekong River water level was found to be $29.2 \%$ and $34.2 \%$, under RCP 4.5 (Figure 4) and RCP 8.5 (Figure 5) respectively.

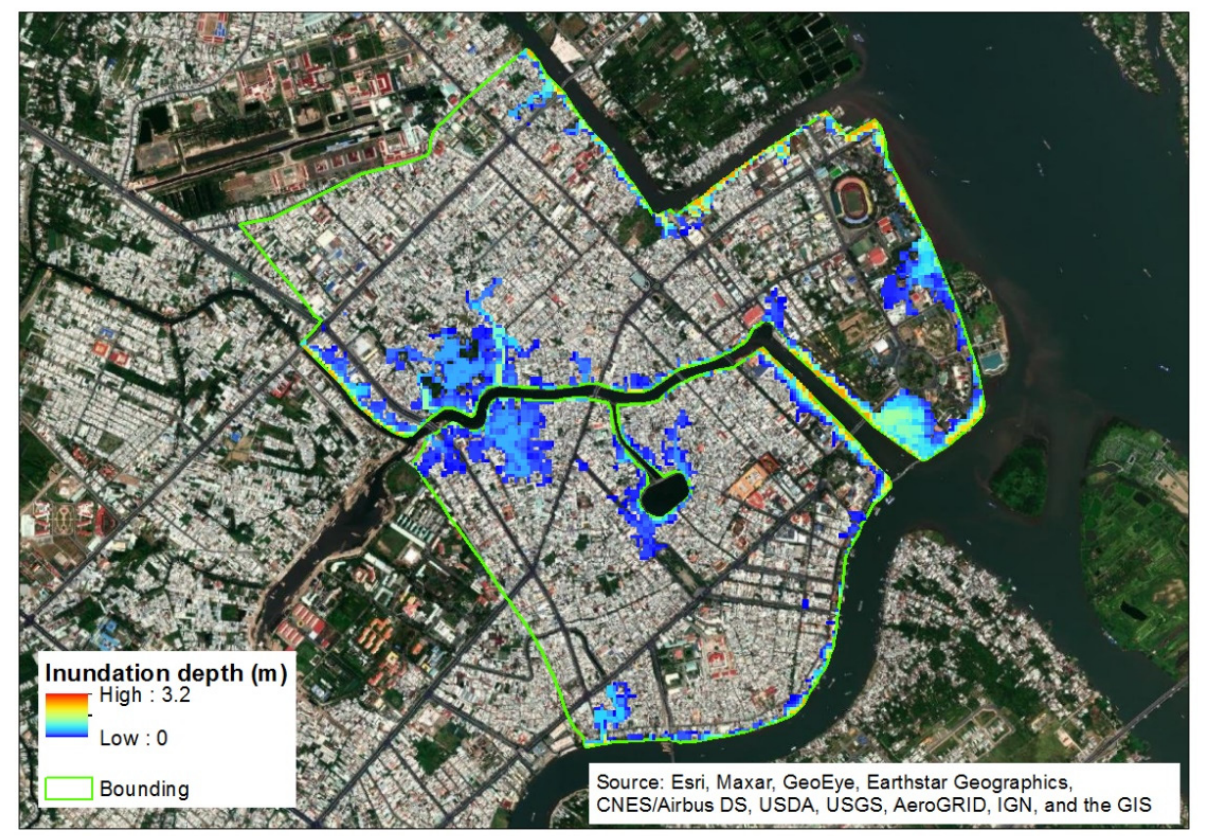

Figure 3. Inundation map corresponding to 100-year return period water level at Can Tho in the year 2020. 


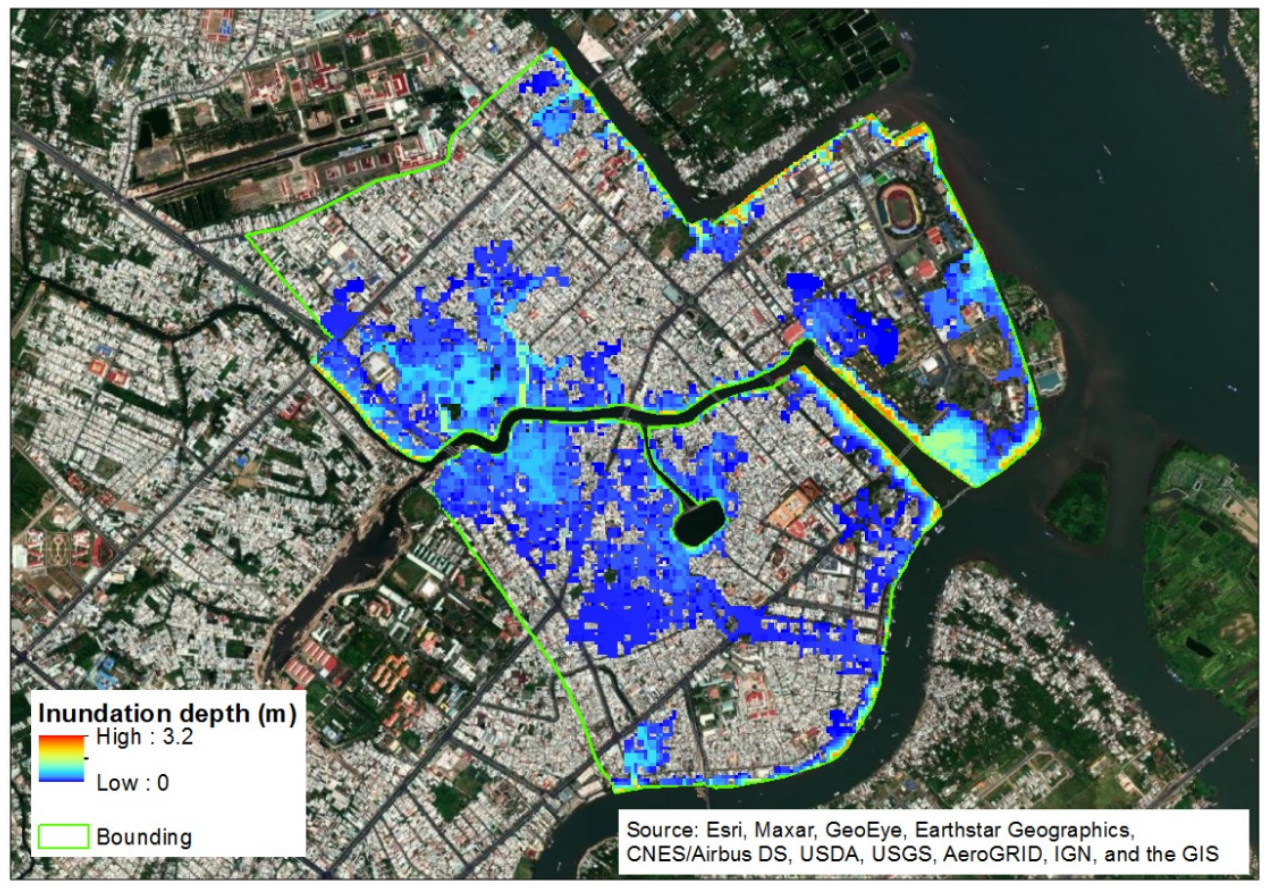

Figure 4. Inundation map corresponding to 100-year return period water level at Can Tho in the year 2050 under RCP 4.5.

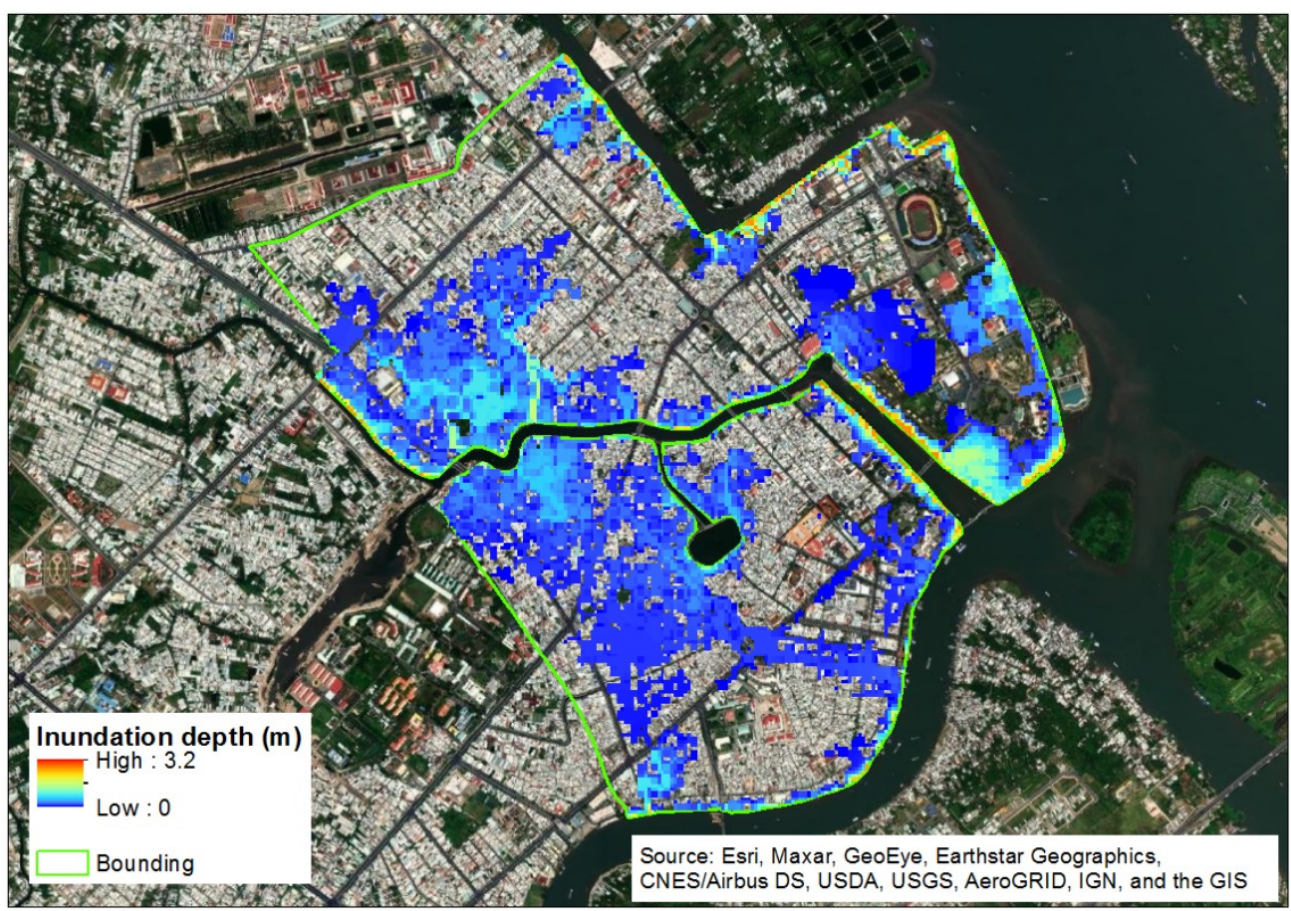

Figure 5. Inundation map corresponding to 100-year return period water level at Can Tho in the year 2050 under RCP 8.5.

Thus, users from the planning and program formulation domain can easily relate the inputs values to future conditions using the available information on climate change in the Mekong Delta and create useful information from the outputs. This would also enable the policymakers to explore strategic planning and policy narratives, such as adaption pathways for Can Tho (e.g., [43]) to adapt to changing climate and mitigate these risks. 


\section{(6) Interpretation and relevance of outputs across a wide spectrum of stakeholders}

Inundation depth at the grid level and the water level of the Mekong River at Can Tho are useful information and when considered together allow the various stakeholders to understand the interdependencies of interventions taken at the various spatial scales. Hence, this information will raise awareness amongst the various stakeholders to collaborate and to identify the challenges and opportunities of interventions taken at the delta level, city level, neighborhood level and property level [44]. The outcome will result in more inclusive and likely new perspectives on FRM in the area. This future flood risk information can be used by strategic planners to formulate delta policies and directives to guide strategic goal setting, future planning and implementation of effective flood mitigation measures in the Mekong Delta.

Similarly, users from the city administration can use future floodwater depth hazard information to ascertain the vulnerability of communities across socio-economic divides and threats to critical infrastructure. This future quantitative information can also be used in public outreach initiatives, such as "Swamped in Melbourne" [45], to create awareness among communities as informed citizenry would be willing to cooperate with other stakeholders toward reduction of flood risk.

Like in most other flooding contexts, floods in Can Tho affect the urban poor and economically weaker sections in the city [46,47]. By overlaying demographical data on the computed flood damages, the impact and vulnerability of different social strata can be determined by the city planners. According to Chinh et al. (2016) [47], the average damage due to the year 2011 flood event at every household was about USD 333/-, whereas the average monthly income of a vulnerable household was USD 185/-. This means these households lose two months of income to floods and have to spend money on their economic recovery as well. Inform can be further updated by integrating gridlevel demographic and socio-economic data to generate the community-specific economic impact and vulnerability maps without any additional input efforts from the user. Such information can help the city administrators to develop location-specific socio-economic interventions, such as providing grants, subsidies, or soft loans for the vulnerable lowincome households to flood-proof their houses [48]; and also to assess the ripple effect of interventions within the neighborhood.

With Inform outputs, city administration officials in Can Tho would be able to combine flood hazard information with the socio-economic profile at those grids and ascertain the vulnerability at those grids [49]. Vulnerability assessment can help the city administration draft targeted awareness campaigns and preparedness measures together with the local communities and disaster relief agencies such as National Red Cross societies. Upon availability of grid-level socio-economic data and infrastructure data, the Inform can be updated to generate a critical infrastructure index and vulnerability map without any additional input efforts from the user.

\section{(7) Assessing the effectiveness of FRM measures}

The two interventions built into Inform represent the delta- or basin-scale action (i.e., reduction in river flow) and the local action at city scale or neighborhood scale (i.e., arresting land subsidence). This information on the effectiveness of the FRM measures can be used by regional- and city-level stakeholders to plan FRM measures. Long term risk-informed perspective enables planners to explore and select adaptation pathways (sequences of measures in time) required to minimize flood risk for different scenarios. These measures encompass (amongst others) changing street profiles, land use planning and zoning based on recommendations such as EEA (2016) [50].

\section{Pilot Testing and Evaluation of Inform}

Inform outputs can be used to create authentic quantitative information (e.g., flood water level, flood hazard and damage maps, as well as estimated food damage corresponding to each flood event) to inform, explore and strategize with several stakeholders through 
the process of collaboration, critical thinking and creativity. This can lead to outcomes, such as awareness, validation, trust, policies, innovations and futuristic planning, etc. Inform is aimed at supporting rapid flood risk assessment and facilitating a co-designing approach to explore, identify and select flood risk reduction measures with stakeholders participation. In order to test and evaluate the tool, a multi-stakeholder co-design meeting was planned as part of the development process. However, due to travel restrictions associated with the Covid-19 pandemic, this co-design meeting in Can Tho did not take place. Hence, a pilot test of the Inform tool was conducted with experts. These participants served as potential stakeholders to mimic the co-design work sessions and were asked to use the online Inform tool. These experts based on their use of the tool and the inputs and outputs generated within the framework of this study for Can Tho to evaluate Inform. The participants were requested to evaluate the tool using seven criteria (Sections 2 and 3) and suggest improvements for each criterion.

Nine experts participated in the pilot testing, including six senior experts and three $\mathrm{PhD}$ researchers covering a range of disciplines such as River Engineering and Water Governance, Hydrology and Water Resource Management, Hydraulic Engineering, Hydroinformatics and Numerical Ocean Modelling.

Each expert received a user manual along with the tool and was requested to send their feedback in writing. The summarised feedback is presented in Table 2.

Table 2. Summary of participants' feedback and suggestions for improving the Inform tool.

\begin{tabular}{|c|c|c|c|}
\hline No. & Criteria & Participants' Feedback & Participants Suggestions to Improve the Tool \\
\hline 1 & $\begin{array}{l}\text { Ensuring reliability } \\
\text { of tool outputs }\end{array}$ & $\begin{array}{l}7 \text { participants said that it is } \\
\text { difficult to evaluate the tool } \\
\text { outputs' reliability due to lacking } \\
\text { information related to the input } \\
\text { data, calibration and validation of } \\
\text { the tool. } \\
2 \text { participants said that the tool's } \\
\text { outputs are coherent with the } \\
\text { selected input data. }\end{array}$ & $\begin{array}{l}\text { - Adding a link/info box with information for users } \\
\text { (e.g., the origin of the input parameters (discharge, } \\
\text { sea level), the tool calibration and validation). } \\
\text { Adding a comparison feature allows the user to see } \\
\text { the output of two consecutive selections at once } \\
\text { instead of resetting the system. } \\
\text { - Increasing the size and resolution of maps. }\end{array}$ \\
\hline 2 & $\begin{array}{l}\text { Ease of use and } \\
\text { avoiding } \\
\text { input overkill }\end{array}$ & $\begin{array}{l}7 \text { participants said that the tool is } \\
\text { easy to use with the friendly-user } \\
\text { interface. } \\
\text { - } 1 \text { participant said that it is moderate. } \\
\text { - } 1 \text { participant did not evaluate } \\
\text { this criterion. }\end{array}$ & $\begin{array}{l}\text { - } \quad \text { Collecting more recent data (discharge, sea level). } \\
\text { - } \quad \text { Adding units of flow, sea level in the } \\
\text { respective graphs. } \\
\text { - } \\
\text { idjusting the tool to ensure that when selecting an } \\
\text { the other one (e.g., sea level) should change } \\
\text { automatically for the same year. } \\
\text { - Creating three or four pre-programmed scenarios. } \\
\text { - Creating an additional Vietnamese version of the tool }\end{array}$ \\
\hline 3 & $\begin{array}{l}\text { Time taken to } \\
\text { generate tool outputs }\end{array}$ & $\begin{array}{l}\text { All participants said that the tool is } \\
\text { rapid in generating the outputs. }\end{array}$ & \\
\hline 4 & $\begin{array}{l}\text { Transcending coarser } \\
\text { and finer resolutions } \\
\text { across spatial scales }\end{array}$ & $\begin{array}{l}\text { - } 3 \text { participants said that the spatial } \\
\text { scales is fine. } \\
\text { - } 2 \text { participants said that it was a } \\
\text { lack of information for evaluation. } \\
\text { - } 4 \text { participants did not evaluate } \\
\text { this criterion. }\end{array}$ & $\begin{array}{l}\text { Adding necessary information such as database or } \\
\text { journal links or info box for the user to understand } \\
\text { about this criterion, including the meaning and } \\
\text { purpose of this criterion. }\end{array}$ \\
\hline
\end{tabular}


Table 2. Cont.

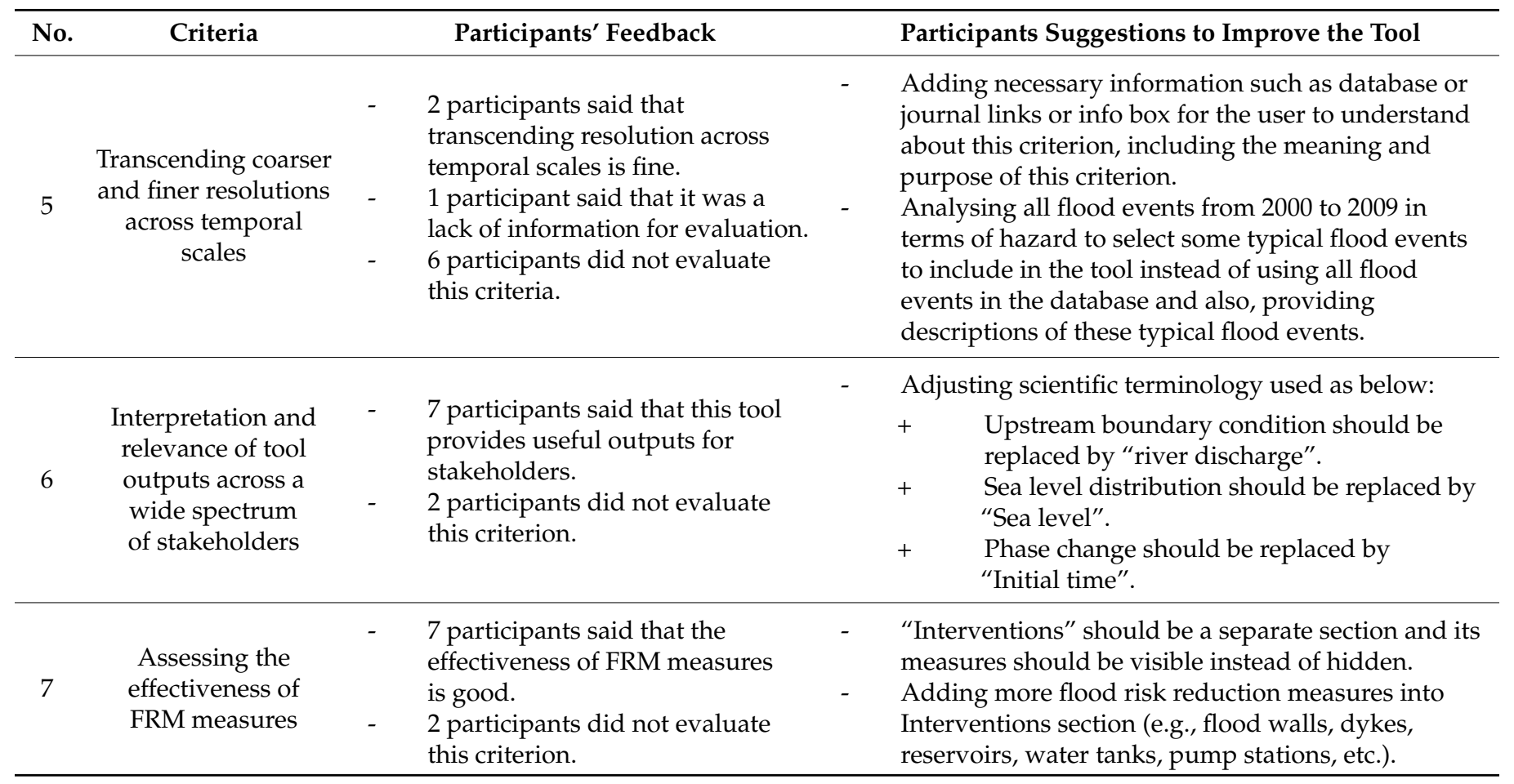

Based on the feedback, 4 out of 7 criteria received a positive evaluation from the participants. The remaining 3 criteria related to reliability of the tool (i.e., transcending coarser and finer resolution across spatial scales, and time scales) could not be thoroughly assessed by the participants as these three parameters are at the back-end of the toolcomprising the model and database that generates these results-and are not evident to the users. As recommended by the expert participants the reliability of these criteria can be improved by adding additional information about the methodology, database and similar tools. Based on the results of this pilot test, it can be concluded that Inform is a user-friendly interactive tool and easy to use even for non-FRM specialists. It satisfies the general user requirements for an interactive tool that is suitable for co-designing work sessions. The tool needs to be further tested with a broader group of stakeholders with different expertise and different experience levels in a multi-stakeholder face-to-face co-design setting, once the COVID-19sanitary regulations are relaxed.

Improvements suggested by the pilot users related to improved ease of use and scientific terminology, etc., will be implemented in the next version of the tool.

\section{Discussion}

Inform has been developed with all the essential features of a co-design tool (e.g., inbuilt input library, flexible options, easy to use, quick results, user-friendly interface) for a wide range of stakeholders. According to Ngo et al. (2020) [24] in Can Tho though people view climate change impacts as temporary and also as spatially and temporally distant, there is a willingness to learn about long-term impacts to resort to adaptation measures. Tools such as Inform can be used to improve the congruency of climate action communication, where the outputs of Inform can be used to frame the messages to stakeholder that are concrete and action-oriented. Contextualized stories or narratives of Can Tho residents and concerned stakeholders across space and time can help the stakeholders from Can Tho to overcome the psychological disconnect. Narratives that are based on gain, loss and fear are effective when targeting behaviour change [51]. Outputs from Inform can be used to generate gain-loss-fear-based narratives on flood risk to promote adaptation behavior in Can Tho. Tools such as Inform can developed and be used by various stakeholders in a 
flood risk context, as well as by researchers from socio-hydrological and/or hydro social domains to understand individual and organizational perceptions about flood risk and FRM interventions.

Expanding the type of FRM interventions: The current version of Inform includes two types of interventions: intervention 1-Reduction of flow due to upstream dams, intervention 2-Land subsidence control in Can Tho city. Inform could be expanded to include local FRM interventions-either at city scale or/and locally (grid level) with soft structural measures, such as swales, wetlands, buffer areas; and hard structural measures, such as heightening of dikes, constructing flood walls, pump station, relocation of critical infrastructure, changing street profiles and flood proofing of houses on the flood hazard, to enable the generation of flood depth and flood damage information. This will result in a powerful decision-making tool. The current version of Inform does not support such calculations as simulating these types of interventions (e.g., building reservoirs, dykes, flood barriers, flood walls, etc.) is beyond the capacity of the 2D model. Flood modelers and online tool developers can jointly explore the possibility of incorporating a suite of FRM interventions such as Climateapp [52] in the flood risk tool. Combining past events and plausible future events can help in testing the effectiveness of FRM measures such as dikes, diversions, green infrastructure or nature-based solutions, land use planning and zoning regulations.

Generating plausible future scenario particulars: Inform can be modified to generate plausible future scenarios. The output will then enable city planners and administrators to explore risk-informed FRM approaches based on a cost-benefit ratio assessment, instead of the standards-based approach, to decide on effective FRM interventions for the future. Additionally, total flood damages and grid-based flood damages can be calculated for different scenarios combinations of RCPs [53] and Mekong Delta Plan scenarios [30]. This will create a wide range of analysis possibilities at the strategic, planning and project implementation level. A thorough exploration of flood damages and flood risk based on these scenarios and using this information to create engagement with stakeholders can lead to enhanced trust and awareness. Additionally, there is scope for developing Inform to be akin to the climate analogs tool [54]. Upon selecting a particular city in Australia and an RCP or a shared-socio economic pathway (SSPs), the climate analogs tool lists out how the climate of that city would be in the future along the RCP and lists similar cities which have a similar climate now. For example, according to the climate analogs tool, under the RCP 8.5 emission scenario in the year 2090, the temperature and number of hottest as well driest days in Sydney will be similar to the hot and dry days of present-day Brisbane. This comparative narrative can help the user better understand how that future climate might feel like as it directly compares with a present-day reality. Inform can be improved to roll out similar flood depth and flood damage analogs comparing cities within the Mekong Delta that would help strategic decision makers or roll out local analogs within the city that help city administrators, communities and individuals understand flood risk.

Expanding objectives of flood risk assessment: There is evidence of floods affecting the health of people in Can Tho, which could also be explored from a public health point of view [55]. Inform can be improved to assess the contribution of, flood risk, on public health and quantifying the associated health risk in the urban center of Can Tho. This will result in a more robust and comprehensive tool to support flood risk assessment for the Ninh Kieu district in the future.

Increasing the applicability and interactivity: Inform can be made compatible to be used through computer and smartphones alike by the literate general public, it can serve as a good FRM outreach tool. Inform can become an integral part of flood risk awareness campaigns in Can Tho, which would lead to outcomes such as more informed autonomous adaptation approaches, align bottom-up and top-down approaches and to build trust among the stakeholders. There is conclusive evidence in cities of Can Tho, Da Nang and Quy Nhon in Vietnam that people resort to coping measures to avoid damages during seasonal flooding events; their intention to implement adaptation measures to minimize or 
eliminate long term flood risk is moderate; and there is a willingness to learn and adapt to long term climate impacts [24]. Tools such as Inform can enable such learning and promote the implementation of adaptation measures.

Inform is a location-specific tool for Can Tho, Vietnam. It is a pilot that is being tested for Can Tho, Vietnam, to enable consultations with a wider range of stakeholders involved in the flood risk management of Can Tho. The background engine of Inform-1D model for the entire Mekong Delta can be used to provide water levels for any location along the Mekong River, whereas the grid-level inundation depths and estimated damages were obtained directly from the 1D/2D coupled model for only Can Tho. The objective of developing this tool is to demonstrate that it is possible to simplify the output of complex hydraulic models to a wider audience using an interactive tool within a short span of time to enable the understanding of the context; understand possible outcomes of interventions planned and their impacts; and, more importantly, encourage discussions between stakeholders so that there is collective decision making and ownership on the decisions being made with respect to FRM. Although Inform is a location-specific tool the underlying principles and methodology can be used to customize the tool for other locations (cities in a river catchment).

\section{Conclusions}

Inform (Instant flood risk modeling), a web-based hydraulic tool has been developed based on a simplified 1D model for the entire Mekong Delta, flood hazard and damage maps, and estimated flood damages for the Ninh Kieu district in Can Tho, Vietnam to support co-designing of FRM strategies. Seven requirements for user-friendly flood risk tool obtained through literature review was used to develop this tool. Inform is an interactive tool that can support probabilistic flood risk assessment and facilitate a co-designing approach for risk reduction measures with the participation of multi-stakeholders. Pilot testing and evaluation of Inform by expert users confirmed that Inform contains features essential for a co-designing tool (e.g., inbuilt input library, flexible options, easy to use, providing quick results, user-friendly interface). Further pilot testing is recommended with a wider group of stakeholders in Can Tho to substantiate the findings and strengthen the tool.

Inform will enable stakeholders to understand the flood risk they will be exposed to. Risk perceptions allow the prediction of individual and community responses, enable policymakers to develop effective strategies, implement risk management interventions that are in line with public expectations, and encourage dialogue and collective learning among stakeholders. Inform can be used for agenda-setting, formulation of plans and implementation of urban FRM objectives in the Mekong Delta.

The interactive web-based tool-Inform-presented here is a tool that supports codesign, adoption and successful implementation of interventions that leads to sustainable infrastructure delivery. In this regard, Inform in its present form or with minor improvements, can assist policy-makers and city administrators achieve sustainable development goals (SDGs), such as SDG 11 (sustainable cities and communities), SDG 13 (climate action) and SDG 17 (partnership for the goals). Inclusion of flood water quality in the flood risk tool can also extend its contribution towards achieving SDG 3, i.e., good health and wellbeing. With the help of an interactive web tool such as Inform presented here, it is possible to co-design FRM strategies for Can Tho or any other city that is subject to flood risk.

Author Contributions: H.N. and M.R. prepared the initial version of the manuscript. R.R., A.P. and C.Z. reviewed the manuscript and provided editorial input. All authors have read and agreed to the published version of the manuscript.

Funding: This research received no external funding.

Acknowledgments: H.N. is supported by IHE Delft projects OPTIRISK, DURA FR Research fund, and AXA CC and CR. R.R. is supported by the AXA Research fund and the Deltares Strategic Research Programme 'Coastal and Offshore Engineering'. The authors would like to thank CHI 
(Computational Hydraulics International) for providing the PCSWMM licence and SURFsara for giving the grant to use the e-infra/SURFsara HPC Cloud.

Conflicts of Interest: The authors declare no conflict of interest. The funders had no role in the design of the study; in the collection, analyses, or interpretation of data; in the writing of the manuscript, or in the decision to publish the results.

\section{References}

1. Alfieri, L.; Bisselink, B.; Dottori, F.; Naumann, G.; De Roo, A.; Salamon, P.; Wyser, K.; Feyen, L. Global projections of river flood risk in a warmer world. Earth's Future 2017, 5, 171-182. [CrossRef]

2. Arnell, N.W.; Gosling, S. The impacts of climate change on river flood risk at the global scale. Clim. Chang. 2014, 134, 387-401. [CrossRef]

3. Forzieri, G.; Cescatti, A.; e Silva, F.B.; Feyen, L. Increasing risk over time of weather-related hazards to the European population: A data-driven prognostic study. Lancet Planet. Health 2017, 1, e200-e208. [CrossRef]

4. Hirabayashi, Y.; Mahendran, R.; Koirala, S.; Konoshima, L.; Yamazaki, D.; Watanabe, S.; Kim, H.; Kanae, S. Global flood risk under climate change. Nat. Clim. Chang. 2013, 3, 816-821. [CrossRef]

5. Kundzewicz, Z.; Kanae, S.; Seneviratne, S.; Handmer, J.; Nicholls, N.; Peduzzi, P.; Mechler, R.; Bouwer, L.M.; Arnell, N.; Mach, K.; et al. Flood risk and climate change: Global and regional perspectives. Hydrol. Sci. J. 2013, 59, 1-28. [CrossRef]

6. Mora, C.; Spirandelli, D.; Franklin, E.C.; Lynham, J.; Kantar, M.B.; Miles, W.; Smith, C.Z.; Freel, K.; Moy, J.; Louis, L.; et al. Broad threat to humanity from cumulative climate hazards intensified by greenhouse gas emissions. Nat. Clim. Chang. 2018, 8, 1062-1071. [CrossRef]

7. UNISDR. 2013 Floods a "Turning Point". Available online: https://undrr.org/news/2013-floods-turning-point (accessed on 3 August 2020).

8. OECD. Financial Management of Flood Risk; OECD Publishing: Paris, France, 2016. [CrossRef]

9. van den Belt, M. Mediated Modeling: A System Dynamics Approach to Environmental Consensus Building; Island Press: Washington, DC, USA, 2004.

10. Beall, A.; Zeoli, L. Participatory modeling of endangered wildlife systems: Simulating the sage-grouse and land use in Central Washington. Ecol. Econ. 2008, 68, 24-33. [CrossRef]

11. Suarez, P.; Ribot, J.C.; Patt, A.G. Climate information, equity and vulnerability reduction. In Distribution Impacts of Climate Change and Disasters: Concepts and Cases; Ruth, M., Ibarrarian, M.E., Eds.; Edward Elgar: Northampton, UK, 2009; pp. 151-165. [CrossRef]

12. Rijke, J.; van Herk, S.; Zevenbergen, C.; Ashley, R.; Hertogh, M.; Heuvelhof, E.T. Adaptive programme management through a balanced performance/strategy oriented focus. Int. J. Proj. Manag. 2014, 32, 1197-1209. [CrossRef]

13. WLI Delft Hydraulics. Hydraulishe Effecten van Maatregelen Bovenrivierengebied: PKB-Studie Deelrapport B; WL I Delft Hydraulics: Delft, The Netherlands, 2003; p. 61.

14. Zhou, Q.; de Bruijn, J.A.; ten Heuvelhof, E.F.; Mayer, I.S. Room to Play: How the Planning Kit Blokkendoos (PKB) Prevent-ed a Deadlock in Water Management. In Learn to Game —Game to Learn; Kin, G.Y., Cai, Y., Eds.; National University of Singapore: Singapore, 2009; pp. 41-50. ISBN 978-981-08-3769-3.

15. Leskens, J.G.; Brugnach, M.; Hoekstra, A. Application of an Interactive Water Simulation Model in urban water management: A case study in Amsterdam. Water Sci. Technol. 2014, 70, 1729-1739. [CrossRef]

16. Faulkner, H.; Parker, D.; Green, C.; Beven, K. Developing a Translational Discourse to Communicate Uncertainty in Flood Risk between Science and the Practitioner. Ambio 2007, 36, 692-704. [CrossRef]

17. Timmerman, J.G.; Beinat, E.; Termeer, C.J.A.M.; Cofino, W.P. A methodology to bridge the water information gap. Water Sci. Technol. 2010, 62, 2419-2426. [CrossRef] [PubMed]

18. Samuels, P.P. Stakeholder Involvement in Flood Risk Management-Contribution from the FLOODsite Project. In Proceedings of the WGF Thematic Workshop on Stakeholder Involvement in Flood Risk Management, Bucharest, Romania, 17-19 April 2012.

19. Leskens, J.G.; Kehl, C.; Tutenel, T.; Kol, T.; De Haan, G.; Stelling, G.; Eisemann, E. An interactive simulation and visualization tool for flood analysis usable for practitioners. Mitig. Adapt. Strat. Glob. Chang. 2015, 22, 307-324. [CrossRef] [PubMed]

20. Scheffran, J. Tools for Stakeholder Assessment and Interaction. In Stakeholder Dialogues in Natural Resources Management: Theory and Practice; Stoll-Kleemann, S., Welp, M., Eds.; Spinger: Berlin, Germany, 2007; pp. 153-185. [CrossRef]

21. Aubert, A.H.; Bauer, R.; Lienert, J. A review of water-related serious games to specify use in environmental Multi-Criteria Decision Analysis. Environ. Model. Softw. 2018, 105, 64-78. [CrossRef]

22. Mintzberg, H.; Raisinghani, D.; Theoret, A. The Structure of "Un-structured" Decision Processes. Adm. Sci. Q. 1976, 21, 246-275. [CrossRef]

23. Maloney, E.K.; Lapinski, M.K.; Witte, K. Fear Appeals and Persuasion: A Review and Update of the Extended Parallel Process Model. Soc. Pers. Psychol. Compass 2011, 5, 206-219. [CrossRef]

24. Ngo, C.C.; Poortvliet, P.M.; Feindt, P.H. Drivers of flood and climate change risk perceptions and intention to adapt: An explorative survey in coastal and delta Vietnam. J. Risk Res. 2019, 23, 424-446. [CrossRef]

25. Brügger, A.; Morton, T.A.; Dessai, S. "Proximising" climate change reconsidered: A construal level theory perspective. J. Environ. Psychol. 2016, 46, 125-142. [CrossRef]

26. Spence, A.; Poortinga, W.; Pidgeon, N. The Psychological Distance of Climate Change. Risk Anal. 2011, 32, 957-972. [CrossRef] 
27. Leelawat, N.; Pee, L.G.; Iijima, J. Mobile Apps in Flood Disasters: What Information do Users Prefer? In Proceedings of the International Conference on Mobile Business, Berlin, Germany, 10-13 June 2013; p. 15.

28. Leiserowitz, A. Climate Change Risk Perception and Policy Preferences: The Role of Affect, Imagery, and Values. Clim. Chang. 2006, 77, 45-72. [CrossRef]

29. Nisbet, M.C. Environment: Science and Policy for Sustainable Development Communicating Climate Change: Why Frames Matter for Public Engagement. Environ. Sci. Policy Sustain. Dev. 2010, 51, 12-23. [CrossRef]

30. MDP. Mekong Delta Plan: Long-Term Vision and Strategy for a Safe, Prosperous and Sustainable Delta; Open Development Mekong: Vietnam, 2013; p. 126. Available online: https:/ / data.opendevelopmentmekong.net/library_record/mekong-delta-plan-longterm-vision-and-strategy-for-a-safe-prosperous-and-sustainable-delta (accessed on 5 November 2021).

31. Rijkswaterstaat. Over Overstroomik? Available online: https://www.overstroomik.nl/ (accessed on 6 August 2020).

32. UK Environment Agency. Check You Long Term Flood Risk. Available online: https://flood-warning-information.service.gov. uk/long-term-flood-risk / (accessed on 6 August 2020).

33. Melbourne Water. Property Flood Level Information. 2019. Available online: https:/ /www.melbournewater.com.au/planningand-building/apply-to-build-or-develop/property-flood-level-information (accessed on 6 August 2020).

34. Ngo, H.; Pathirana, A.; Ranasinghe, R.; Radhakrishnan, M. Inform, an Instant Flood Risk Modelling Tool for Can Tho City in Mekong Delta, Vietnam. 2020. Available online: https:/ / fg.srv.pathirana.net (accessed on 5 October 2021).

35. Ngo, H.; Pathirana, A. Repository of Source Code and Flood Damage Data for the Instant Flood Risk Modelling Tool (Inform) for Can Tho. 2020. Available online: https://zenodo.org/record/3968532\#.Xyp3gygzY2w (accessed on 2 September 2021).

36. DWF. Survey on Perception of Risk in Can Tho City; DWF: Lauzerte, France, 2011; p. 182.

37. SCE. Comprehensive Resilience Planning for Integrated Flood Risk Mangement for Can Tho. Available online: https:/ / sce.fr/ en/comprehensive-resilience-planning-integrated-flood-risk-management-can-tho-vietnam (accessed on 7 August 2020).

38. Ngo, H.; Pathirana, A.; Zevenbergen, C.; Ranasinghe, R. An Effective Modelling Approach to Support Probabilistic Flood Forecasting in Coastal Cities-Case Study: Can Tho, Mekong Delta, Vietnam. J. Mar. Sci. Eng. 2018, 6, 55. [CrossRef]

39. Ngo, H.; Ranasinghe, R.; Zevenbergen, C.; Kirezci, E.; Maheng, D.; Radhakrishnan, M.; Pathirana, A. An efficient modelling approach for probabilistic assessments of present-day and future fluvial flooding. Front. Clim. 2021. submitted.

40. Seijger, C.; Hoang, V.T.M.; Van Halsema, G.; Douven, W.; Wyatt, A. Do strategic delta plans get implemented? The case of the Mekong Delta Plan. Reg. Environ. Chang. 2019, 19, 1131-1145. [CrossRef]

41. Radhakrishnan, M.; Pathirana, A.; Ashley, R.; Zevenbergen, C. Structuring Climate Adaptation through Multiple Perspectives: Framework and Case Study on Flood Risk Management. Water 2017, 9, 129. [CrossRef]

42. Hoang, L.P.; Lauri, H.; Kummu, M.; Koponen, J.; van Vliet, M.T.H.; Supit, I.; Leemans, R.; Kabat, P.; Ludwig, F. Mekong River flow and hydrological extremes under climate change. Hydrol. Earth Syst. Sci. 2016, 20, 3027-3041. [CrossRef]

43. Radhakrishnan, M.; Nguyen, H.Q.; Gersonius, B.; Pathirana, A.; Vinh, K.Q.; Ashley, R.M.; Zevenbergen, C. Coping capacities for improving adaptation pathways for flood protection in Can Tho, Vietnam. Clim. Chang. 2017, 149, 29-41. [CrossRef]

44. Nguyen, H.Q.; Radhakrishnan, M.; Bui, T.K.N.; Tran, D.D.; Ho, L.P.; Tong, V.T.; Huynh, L.T.P.; Chau, N.X.Q.; Ngo, T.T.T.; Pathirana, A.; et al. Evaluation of retrofitting responses to urban flood risk in Ho Chi Minh City using the Motivation and Ability (MOTA) framework. Sustain. Cities Soc. 2019, 47, 101465. [CrossRef]

45. Bertram, N.; Murphy, C.; Pasman, R.; Rogers, B.; Gunn, A.; Urich, C.; Arnbjerg-Nielsen, K.; Lowe, R.; Radhakrishnan, M.; Gersonius, B. Swamped, Swamped-The Gallery, Victoria, Australia, 22 February 2017 to 22 March 2017; The City of Port Phillip: Port Phillip City, VIC, Australia, 2017.

46. Chinh, D.T.; Gain, A.K.; Dung, N.V.; Haase, D.; Kreibich, H. Multi-Variate Analyses of Flood Loss in Can Tho City, Mekong Delta. Water 2016, 8, 6. [CrossRef]

47. Chinh, D.T.; Bubeck, P.; Dung, N.V.; Kreibich, H. The 2011 flood event in the Mekong Delta: Preparedness, response, damage and recovery of private households and small businesses. Disasters 2016, 40, 753-778. [CrossRef]

48. Radhakrishnan, M.; Islam, T.; Ashley, R.M.; Pathirana, A.; Quan, N.H.; Gersonius, B.; Zevenbergen, C. Context specific adaptation grammars for climate adaptation in urban areas. Environ. Model. Softw. 2018, 102, 73-83. [CrossRef]

49. Garschagen, M. Risky Change? Vietnam's Urban Flood Risk Governance between Climate Dynamics and Transformation. Pac. Aff. 2015, 88, 599-621. [CrossRef]

50. EEA. Urban Adaptation to Climate Change in EUROPE 2016: Transforming Cities in a Changing Climate; European Environment Agency, Publications Office of the European Union: Luxembourg, 2016; ISBN 9789292137427.

51. Wilson, D.K.; Purdon, S.E.; Wallston, K.A. Compliance to health recommendations: A theoretical overview of message framing. Health Educ. Res. 1988, 3, 161-171. [CrossRef]

52. Adaptation Solutions. Available online: https://www.climateapp.nl/ (accessed on 6 August 2020).

53. IPCC. Working Group I Contribution to the IPCC Fifth Assessment Report, Climate Change 2013: The Physical Science Basis; Summary for Policymakers; IPCC: Geneva, Switzerland, 2013. Available online: http:/ / www.climatechange2013.org/images/uploads / WGIAR5-SPM_Approved27Sep2013.pdf (accessed on 7 August 2020).

54. CSIRO and Bureau of Meteorology. Climate Change in Australia Website. Available online: https:/ / www.climatechangeinaustralia. gov.au/en/climate-projections/climate-analogues/analogues-explorer/ (accessed on 10 August 2020).

55. Nguyen, H.Q.; Huynh, T.T.N.; Pathirana, A.; Van Der Steen, P. Microbial Risk Assessment of Tidal-Induced Urban Flooding in Can Tho City (Mekong Delta, Vietnam). Int. J. Environ. Res. Public Health 2017, 14, 1485. [CrossRef] [PubMed] 